\title{
Banking Rating Systems for IRB: Comparison of Three Systems from German-speaking Environment
}

\author{
Martin Svítil \\ Soukromá vysoká škola ekonomická Znojmo \\ Loucká 656/21, 66902, Znojmo \\ E-mail: svitil.martin@svse.cz
}

\begin{abstract}
The aim of the article is to compare several rating systems used by banks and their affiliates, especially in German-speaking countries. The research is focused on the rating of business entities, more precisely the corporate ones, (especially limited liability companies or joint-stock companies). In particular, two aspects of the rating of the corporations are highlighted in the rating system comparison, namely: (i) which quantitative indicators are used for the calculation of the hard-facts and (ii) how the soft-facts are included in the rating system. The result of the research shows, that concerning the quantitative indicators (i), the highest emphasis is put on the capital structure of an enterprise (whether in the form of Equity to Liabilities or Equity to Total assets) in all compared rating systems. Concerning the other indicators used for the calculation, the monitored rating systems are different, and the total number of indicators also differs (from 6 to 9). For soft-facts (ii) all rating systems agree on some of the queries (e.g. the sensitivity of the rated entity to market fluctuations), but otherwise the number and the topics of the queries overlap only partially.
\end{abstract}

Keywords: hard-facts, rating, risk management, soft-facts

JEL codes: G11, G21, G24, G32

\section{Introduction}

Internal rating systems are currently an integral part of the risk management system of banks and non-banking financial institutions. In addition to the original purpose, which is the assessment of clients' creditworthiness, they also play an irreplaceable role in determining the capital adequacy of banks in compliance with the Basel II accord and the emerging Basel III accord respectively. For more information about the Basel accords please refer to Basel II (2006) or BIS (2010).

This article deals with the comparison of the internal rating systems used currently and / or in the recent past by three banks or banking groups originating from the German-speaking economic environment and regions. All the banks mentioned apply the IRB Approach for Basel II and use their rating tools to assess the credit risk of their clients, expressed in the PD (probability of Default).

As the issue of rating systems is quite extensive, I focus only on selected matters of the rating systems mentioned here, namely: (i) which quantitative indicators are used for the calculation of the hard-facts (quantitative analysis based on data from reports, especially balance sheets and profit and loss accounts); and (ii) how the soft-facts are included in the rating system (qualitative indicators usually based on a questionnaire or interview). 


\section{Review of Literature}

A similar topic, but from different point of view was studied by Bakhtiari (2017). His paper focuses on the Standard and Poor's ( $\&$ \&) credit rating of firms in the USA. Bakhtiari tried to find positive or negative correlation between the credit rating and productivity of companies. The findings of the paper point to size as to one major balancing factor for a good rating result. With a focus on manufacturing, the evidence points to two types of companies getting an investment grade rating: (i) medium-sized productive firms (firms "driving the creative destruction" according to Bakhtiari) and (ii) very large but not so productive firms (too-big-to-fail and "resisting the creative destruction"). The Bakhtiari's results suggest that the substitutability of size and productivity in the ratings system is not recent and has been around for a long time. In this context, the effort to find the most important factors for the rating results and the potential change of the weights of these factors with size of the rated company makes sense. The size of the rated company (bank's client) and its importance for the rating result is one of the topics I deal with in this paper.

Jankowitsch, Pichler and Schwaiger (2007) analyze the potential economic value of improving the credit rating system. They show, that an investment in the rating system can bring not only a reduction in Basel's required capital held in the bank but also a reduction in credit losses by increasing the annual rate of return by $30-$ 40 bps. Their results demonstrate "the significant potential economic value to a lender of better rating systems because these ratings allow the banks to price loans more effectively." It is questionable, how far can the banks in high-competitive environment on current market really adjust the prices of their loans by risk - since 2007, many things have changed, especially because of the financial crisis. But the more effective rating system and the following better risk evaluation is surely an advantage by all means and in any environment, as stated e.g. by Spuchláková, Valašková, Adamko (2015): "The effective management of credit risk is a critical component of a comprehensive approach to risk management and essential to the long-term success of any banking organization."

One of the most recent as well as geographically closest researches about credit rating is the work of Weissova, Kollar and Siekelova (2015), who deal with the situation in Slovakia. Their paper shows very similar structuring of the rating system(s) to hard- and soft-facts (see below), but they do not deal with more detailed analysis of the indictors used in these categories.

Berg and Koziol (2017) in their paper, covering 40 banks and 17,000 corporate borrowers from 2008-2012 in Germany, found three main results, related to banks' rating systems and their results. (i) First, the variability of PD estimates for the same borrower across banks is large. (ii) Second, bank fixed effects explain $5 \%$ of the variation in PD estimates across banks, while $95 \%$ of the variation is idiosyncratic (non-systematic and thus not affecting capital requirements). (iii) Third, there are various bank characteristics that explain the size of bank fixed effects, like that weaker-capitalized banks on average report lower PD estimates 
and that banks' reported PD estimates increase after significant capital increases. But as the authors emphasize, their results should be interpreted with care.

For the basic overview and historical background about credit rating agencies (I mention the agencies as source for external ratings in point 3.2 and use the Moody's scale for comparison in point 3.5) the paper of Jeon and Lovo (2013) can be recommended.

Danielsson (2002) and Danielsson, Song Shin and Zigrand (2004) show on the example of market risk and value-at-risk models ( $\mathrm{VaR}$ ), that if many players on the same market use the same or similar risk models, it could have very negative consequences. If many market participants apply the same or very similar strategy at the same time, it can make the fluctuation bigger and the situation worse. Although this study covers market risk and value-at-risk models, the degree of similarity can be an interesting question in different types of models too.

The most authors mentioned above use more statistical point of view, thus they usually do not analyze the internal structure of the rating systems / tools. I try to answer the question, how far the credit risk models (banks' internal rating models) are similar and what are the most important factors of rating results, with awareness of limits of available data (regarding the region, the number of monitored banks etc).

Fracassi, Petry and Tate (2016) were concerned with interesting question of how rating analyst subjectivity affects corporate debt pricing. In my paper, I can only briefly mention the soft-facts part of the rating systems (where there is the only potential space for rating analyst subjectivity), but I see this topic as possible direction for future studies.

\section{Data and Methodology}

For comparison, documentation to the three rating systems used by three different banks (banking groups) from the German-speaking environment was available. The data from years 2004 up to 2016 were used, where the most important documents (rating manuals, scales etc.) are dated 2004, 2008, 2011 and 2016.

Since some of these documents are confidential and have not been granted full disclosure, the results of the investigations are limited in some respects. It is also not possible to publish the names of the mentioned banks (banking groups). The data are anonymised accordingly, but this is done in a way which does not affect their value to the research. These three banking institutions and their rating systems are listed under A, B and C. Due to the sensitivity of both client and own bank data, it was not possible to obtain more detailed information or even numerical data on outputs of rating systems. Therefore, the paper is more focused on the comparison of the rating methods and rating systems, not on numerical results.

In all cases, the rating tools are used in a form of a software tool for Microsoft Windows OS. The empirical data was collected and assessed according to the 
criteria of verifiability and relevance. Subsequently, the induction method was applied and conclusions were generalised.

\section{Results and Discussion}

\subsection{Scopes of Rating Systems}

The research is focused on the rating of business entities, more precisely corporate, (especially limited liability companies or joint-stock companies). It does not take into account the rating of natural persons or non-profit organizations, municipalities etc.

Nevertheless, the criteria and limits for the decision, which module (or rating tool included in the rating system) should be used for particular client, are not such simple and differ from bank to bank slightly.

Bank A uses two criteria for the enterprise entities, as the Table 1 shows: (i) operating revenue (consolidated, if applicable) and (ii) group exposure (according to Basel II rules, which means total of all credit lines without term loans plus original amount of outstanding term loans plus account balances exceeding credit lines). For (i) operating revenue the limit is set to EUR 50 million, for (ii) group exposure to EUR 1 million. If the client exceeds at least one of the limits, the bank uses the Corporate rating tool for him. If not, the Retail rating / Scoring tool is used, as the following table shows.

Table 1 The bank A criteria for decision between Retail / Scoring and Corporate rating tools

\begin{tabular}{llll}
\hline & \multicolumn{2}{c}{ Consolidated operating revenue } \\
\cline { 3 - 4 } & & SEUR 50 million & $>$ EUR 50 million \\
\hline \hline \multirow{2}{*}{ Group } & $\leq$ EUR 1 million & Retail / Scoring & Corporate rating \\
\cline { 2 - 4 } & $>$ EUR 1 million & Corporate rating & Corporate rating \\
\hline
\end{tabular}

Source: Author by using bank " $A$ " rating manual

Besides these rules, for some other types of enterprises the Corporate rating tool is used automatically, regardless of the quantitative criteria mentioned above. This is the case for holding companies, real estate private (except for non-reporting companies), non-profit housing construction companies, insurance companies, political parties and non-banking financial institutions. By contrast, for the banks there is a different special rating tool.

Bank B does not use quantitative criteria for the decision of using the corporate rating tool. The rating in Corporate tool should be always based on audited financial statements or at least on data with "certified expert's confirmation of conformity". Special different tool is used for financial companies like banks, leasing companies, insurance companies etc. 
Bank C does not use the quantitative criteria either, but its rating system has more different tools, designed for particular groups of clients like start-ups (new companies with no full year financial results), real estate companies / projects and financial companies (banks, insurance companies). The request for audited financial statements for the Corporate rating tool is set, too.

\subsection{Basic Structure of Rating Systems}

The basic structure of all the three rating systems mentioned is quite similar. All three compared rating systems first produce the part of the rating, based on clients' financial statements (financial data). After possible other inputs like sector data, budgets etc., the financial statement rating becomes quantitative or hard-facts (HF) rating, as one of the two main sources for the final result. The second source is the qualitative or soft-facts (SF) rating, based on qualitative criteria, where usually the key account manager provides most of the information used (for details of the quantitative and qualitative indicators used see below - points 3.3 and 3.4).

In the next stage, the hard-facts rating and the soft-facts rating are integrated together, according to a given weighting formula. This formula differs slightly at the compared rating tools, reaching from $66: 34$ (HF : SF) up to $50: 50$. Two rating systems (banks $A$ and $B$ ) use fix weights for all their corporate clients, the rating system of the bank $C$ is more complex, with the weights varying with a change of the size of the rated company. The more turnover the rated company makes; the more weight the hard-facts have in the final rating. This is a logical solution: smaller companies are more endangered by one person's mistakes or loss (like death of the owner / CEO in one person), their processes (like accounting etc.) are usually less intensively checked by internal and external audits etc. The weights in the bank's $C$ system start with the 50 : 50 ratio for companies with annual turnover under EUR 1 million and continue with increasing importance of quantitative (hard-facts) indicators up to 66 (HF) : 34 (SF) ratio for companies with turnover over EUR 75 million a year. Using the weights, the hard-facts rating and the soft-facts rating result together in an automatically calculated or standalone rating. From this point on, the rating systems start to differ.

Bank A considers first the age of the financial statements, used for the calculation. If they are older than 18 or 21 months respectively (closing day of the latest financial statement), the rating is downgraded by two or three grades respectively. If the dates are older than 24 months, the rating is automatically downgraded to grade 7 (the worst non-default grade). After this step, the rating becomes Recommended rating.

It has to be mentioned, that the other two banks ( $B$ and $C$ ) take the age of the financial statements in consideration too, but in different ways. The bank's $B$ system just does not allow to make a rating from financial statements older than 3 years. In case the statements are between 2 and 3 years, the system shows a notice, but does not change the rating result. For the bank $C$, the financial 
statements older than 21 months are one of the risk factors, considered in the rating process (see below).

Next step in the bank's A rating system are the possible downgrades due to negative information like high dependency on suppliers and / or customers, high write-downs, negative business prospects etc. This information can make the rating worse by several grades or downgrade it directly to the grade 7 .

The last possible change of the rating comes with up- / downgrading or even overruling of the client's rating by using the external credit rating (made by one of respected agencies) or group's, mother's or guarantor's rating - the particular rules are given. When this last step is made or skipped, the rating becomes Final customer's rating. The basic structure of the bank $A$ rating system is shown Figure 1.

Figure 1 The basic structure of the bank A rating system

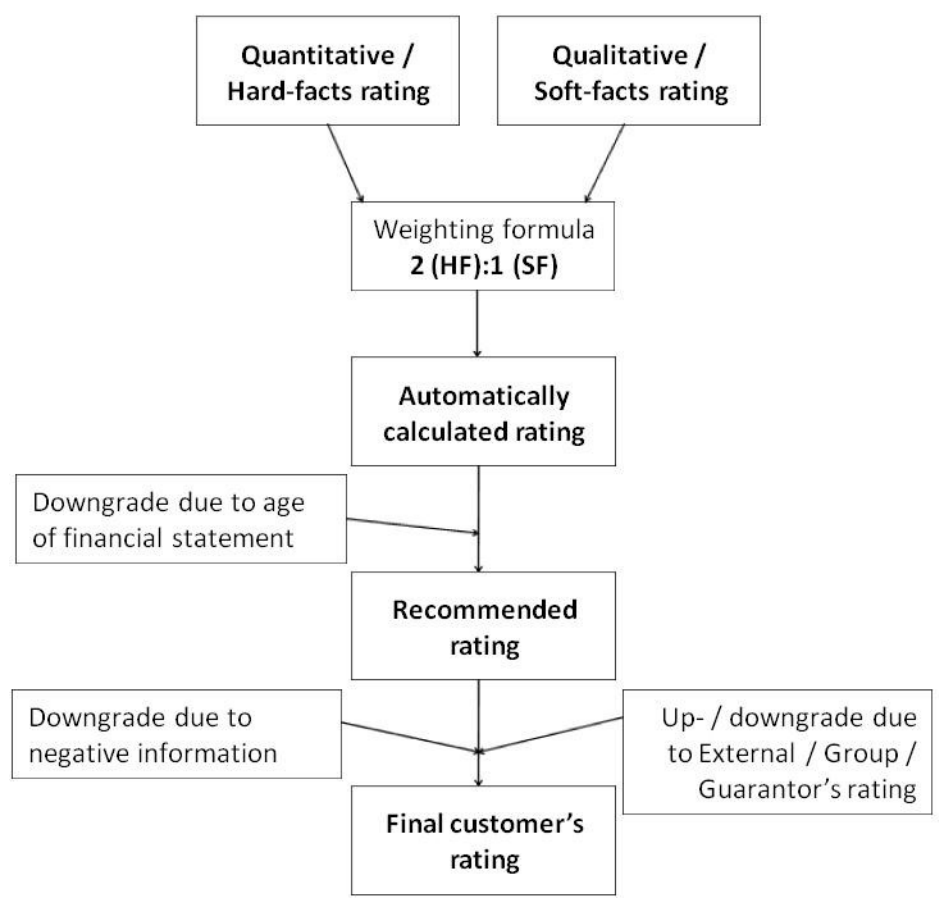

Source: Author's illustration based on Bank A rating manual

In the case of bank B, the external rating could be used too, but only if the customer's shares are traded on stock exchange. In such a case, the external rating influences the hard-facts rating.

In following steps, the basic structure of the rating system is similar to bank $A$, except that the possible up- / downgrades are made just in one step, making Stand - alone rating to Final customer's rating. The basic structure of the bank $B$ rating system in shown Figure 2 . 
Figure 2 The basic structure of the bank B rating system

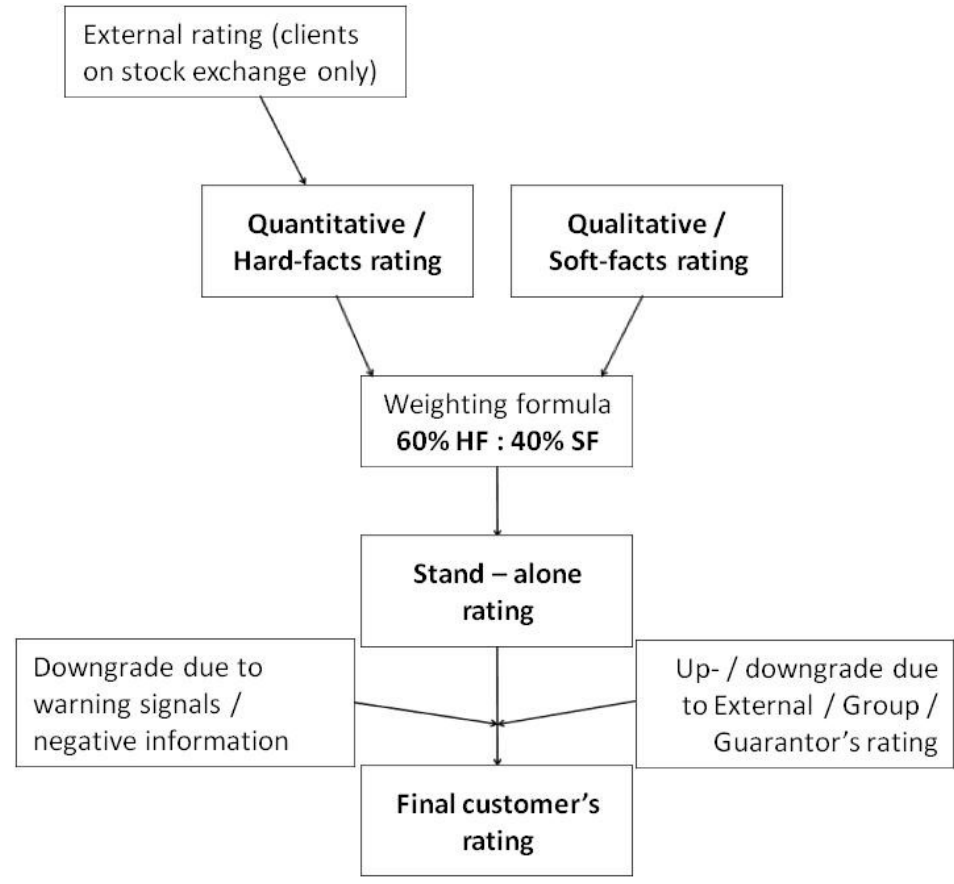

Source: Author's illustration based on Bank B rating manual

The bank $\mathbf{C}$ uses the variable weighting formula for hard- and soft-fact (as mentioned above), in following steps there is one interesting difference between banks $A$ and $B$. Generally, the possible manual down- or upgrades in ratings (in all monitored banks A, B and C) can be made either by any person of the risk management team with the supervision of team head or can be made by chosen person(s) only. The four eye principle (maker - checker) is always kept. But only in the bank's $C$ rating system, after the Automatically calculated rating is made, the relationship manager / salesman has the opportunity to manually downgrade the rating by selecting the risk factors / warning signals. There is no way for the relationship manager / salesman to upgrade the rating and any change has to be approved by a member of risk management. The possible reasons for downgrade can be for example the age of the financial statement (more than 21 months), high amount of doubtful receivables (not noticed in the financial statements, but known to the bank), restructuring non-trustworthy financial statements etc. Obviously the idea is that the salesperson knows the client better because of the personal contacts and visits than a risk manager does.

Then follows the possible correction of the rating by risk management and possible overruling by mother company's rating. The result is the Final customer's rating. The basic structure of the bank $C$ rating system is shown the Figure 3. 
Figure 3 The basic structure of the bank $C$ rating system

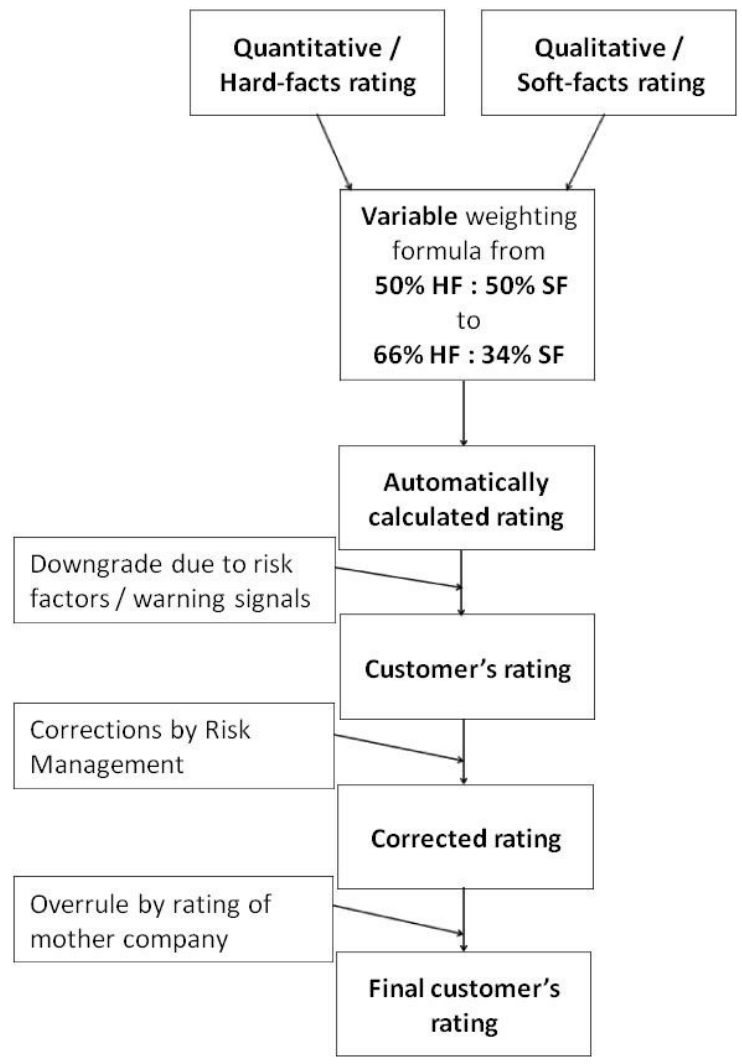

Source: Author's illustration based on Bank C rating manual

\subsection{Quantitative Indicators (Hard-facts)}

For comparison of quantitative as well as qualitative indicators, the overview scheme including all three rating systems was made by author of this paper. In some cases, the weight applies for two or three indicators together, which is represented by the merged and centered particular column in the scheme. Please note that the numbers of weights are rounded.

As the Table 2 shows, regarding the quantitative indicators (hard-facts), the highest emphasis is put on the Capital structure of the rated company. This applies to all three rating systems compared, whether in the form of Equity to Liabilities or Equity to Total assets. Two rating systems pair the Equity ratio with other one or two ratios respectively, concerning Liabilities.

There are three other categories of quantitative indicators (hard facts), used in specific form in all three rating systems. These indicators are (i) Cash Flow to Liabilities (in two cases together with Income to Interest in slightly different form), (ii) Profit to Sales (in one case together with Profit to Total Assets) and (iii) Trade 
payables and Notes payable to Sales; all these indicators have important, but lower weight than the capital structure of the company.

Table 2 Quantitative indicators (hard facts)

\begin{tabular}{|c|c|c|c|c|c|c|c|c|}
\hline \multicolumn{3}{|c|}{ Rating A } & \multicolumn{3}{|c|}{ Rating B } & \multicolumn{3}{|c|}{ Rating C } \\
\hline - & & & \multirow{3}{*}{ Leverage } & \multirow{3}{*}{$38 \%$} & $\begin{array}{l}\text { (Current liabilities } \\
\text { - Cash \& } \\
\text { Equivalents) / } \\
\text { Total Assets } \\
\end{array}$ & - & & \\
\hline Indebtedness & \multirow[t]{2}{*}{$29 \%$} & $\begin{array}{l}\text { (Trade payables } \\
\text { + bank liabilities } \\
\text { + notes } \\
\text { payable) / } \\
\text { (Liabilities + } \\
\text { provisions) }\end{array}$ & & & $\begin{array}{l}\text { (Trade payables } \\
\text { + Notes payable } \\
\text { + interest } \\
\text { bearing liabilities) } \\
\text { / (Liabilities - } \\
\text { Advances) } \\
\end{array}$ & - & & \\
\hline Equity ratio & & $\begin{array}{l}\text { Equity / } \\
\text { Liabilities }\end{array}$ & & & $\begin{array}{l}\text { Equity / Total } \\
\text { assets }\end{array}$ & $\begin{array}{l}\text { Capital } \\
\text { structure }\end{array}$ & $35 \%$ & $\begin{array}{l}\text { Equity / Total } \\
\text { assets }\end{array}$ \\
\hline \multirow[b]{2}{*}{$\begin{array}{l}\text { Financial } \\
\text { Strength }\end{array}$} & \multirow[b]{2}{*}{$24 \%$} & $\begin{array}{l}\text { Operating } \\
\text { Income / } \\
\text { (Interest + } \\
\text { similar } \\
\text { expenses) } \\
\end{array}$ & - & & & $\begin{array}{l}\text { Interests } \\
\text { coverage }\end{array}$ & $23 \%$ & $\begin{array}{l}\text { (EBT + Financial } \\
\text { expenses) / } \\
\text { Financial } \\
\text { expenses }\end{array}$ \\
\hline & & $\begin{array}{l}\text { (Profit or Loss of } \\
\text { the Year }+ \\
\text { Depreciation and } \\
\text { Amortization) / } \\
\text { Liabilities }\end{array}$ & $\begin{array}{l}\text { Debt } \\
\text { coverage }\end{array}$ & $9 \%$ & $\begin{array}{l}\text { Cash Flow / } \\
\text { (Liabilities - } \\
\text { Advances) }\end{array}$ & $\begin{array}{l}\text { Debt } \\
\text { coverage } \\
\text { by } \\
\text { operating } \\
\text { CF }\end{array}$ & $9 \%$ & $\begin{array}{l}\text { (Operating } \\
\text { Income + } \\
\text { Depreciation } \\
\text { and } \\
\text { Amortization + } \\
\text { Financial } \\
\text { expenses) / } \\
\text { (Bank liabilities - } \\
\text { Cash and } \\
\text { equivalents - } \\
\text { bank accounts) }\end{array}$ \\
\hline \multicolumn{3}{|c|}{ Rating A } & \multicolumn{3}{|c|}{ Rating B } & \multicolumn{3}{|c|}{ Rating C } \\
\hline Profitability & $17 \%$ & $\begin{array}{l}\text { (Operating } \\
\text { Income }+ \\
\text { Depreciation and } \\
\text { Amortization) / } \\
\text { Sales } \\
\end{array}$ & \multirow{2}{*}{ Profitability } & \multirow{2}{*}{$25 \%$} & $\begin{array}{l}\text { Ordinary profit / } \\
\text { Sales }\end{array}$ & \multirow[t]{2}{*}{ Profitability } & $8 \%$ & $\begin{array}{l}\text { (EBT + } \\
\text { Depreciation } \\
\text { and } \\
\text { Amortization) / } \\
\text { Sales }\end{array}$ \\
\hline- & & & & & $\begin{array}{l}\text { (Net profit + } \\
\text { Interest Expenses } \\
\text { + Income Taxes } \\
\text { + Depreciation) / } \\
\text { Total Assets } \\
\end{array}$ & & & \\
\hline Growith & $8 \%$ & $\begin{array}{l}\text { Sales }(N)- \\
\text { Sales }(N-1)) / \\
\text { Sales }(N-1) \\
\end{array}$ & Growith & $7 \%$ & $\begin{array}{l}\text { Sales / Previous } \\
\text { Year's Sales }\end{array}$ & - & & \\
\hline Liquidity & $6 \%$ & $\begin{array}{l}\text { (Cash }+ \\
\text { equivalents) / } \\
\text { Working Capital }\end{array}$ & - & & & Liquidity & $10 \%$ & $\begin{array}{l}\text { (Cash and } \\
\text { equivalents }+ \\
\text { bank accounts) / } \\
\text { Working capital }\end{array}$ \\
\hline $\begin{array}{l}\text { Capital tied- } \\
\text { up }\end{array}$ & $16 \%$ & $\begin{array}{l}\text { (Trade payables } \\
\text { + notes } \\
\text { payable) / Sales }\end{array}$ & Activity & $10 \%$ & \begin{tabular}{|l|}
$(($ Notes payable \\
+ Trade \\
payables $) * 360) /$ \\
Sales \\
\end{tabular} & $\begin{array}{l}\text { Turnover of } \\
\text { liabilities }\end{array}$ & $15 \%$ & $\begin{array}{l}\text { Trade payables / } \\
\text { Sales }\end{array}$ \\
\hline- & & & Productivity & $11 \%$ & $\begin{array}{l}\text { Personnel } \\
\text { expenses / Sales }\end{array}$ & - & & \\
\hline
\end{tabular}

Note: The numbers of weights are rounded.

Source: Author' illustration based on banks "A", "B" and " $C$ " rating manuals.

In two cases, the indicators for Growth and for Liquidity are used, in slightly different forms. For the rating system B, where the most indicators (nine) occur, the unique one measures Personnel expenses against Sales with $10 \%$ weight (rounded). 


\subsection{Qualitative Indicators (Soft-facts)}

The Comparison of qualitative (soft-facts) indicators is made by high-level categories, because of keeping the scheme uncluttered. The extent of this paper does not allow to perform a deeper analysis of this topic, too.

It should be mentioned, that in every high - level category (topic) more particular questions / opinions are concentrated. Answering of the questions and making of the soft-facts rating is usually a result of collaboration of key account manager / relationship manager / banker (which can be just different names for very similar positions in the banks) and the member of risk management team or Chief risk officer respectively. In all cases, the four-eye principle is kept, with respect to possible subjectivity of both involved persons, especially the key account manager / relationship manager / banker (who usually gets benefit for every deal made).

Anyway, the scheme shows apparently, that all the rating systems agree on some of the categories, but the similarity is lower than by quantitative indicators and the topics of the queries overlap only partially. The Table 3 shows the qualitative indicators of all three rating systems.

Table 3 Qualitative indicators (soft-facts)

\begin{tabular}{|c|c|c|c|c|c|}
\hline \multicolumn{2}{|l|}{ Rating A } & \multicolumn{2}{|l|}{ Rating B } & \multicolumn{2}{|l|}{ Rating C } \\
\hline Management & $15 \%$ & Strategy & $17 \%$ & Management & $30 \%$ \\
\hline $\begin{array}{l}\text { Internal organisation } \\
\text { (Accounting, Technology) }\end{array}$ & $15 \%$ & - & & Accounting & $20 \%$ \\
\hline & & & & $\begin{array}{l}\text { Qualifications of employees / } \\
\text { Technology }\end{array}$ & $10 \%$ \\
\hline Market / Industry & $15 \%$ & Influence / Market position & $27 \%$ & $\begin{array}{l}\text { Market incl. supplier and } \\
\text { customer structure }\end{array}$ & $30 \%$ \\
\hline Relationship with the bank & $40 \%$ & - & & Relationship with bank & $10 \%$ \\
\hline $\begin{array}{l}\text { Miscellaneous (Age of the } \\
\text { company, Location...) }\end{array}$ & $15 \%$ & $\begin{array}{l}\text { Economic situation (general, } \\
\text { influence on the company) }\end{array}$ & $27 \%$ & & \\
\hline & & $\begin{array}{l}\text { Divergence from planning in } \\
\text { last } 3 \text { yrs. }\end{array}$ & $15 \%$ & & \\
\hline & & $\begin{array}{l}\text { Business expectations incl. } \\
\text { bank's view }\end{array}$ & $15 \%$ & & \\
\hline
\end{tabular}

Note: The numbers of weights are rounded.

Source: Author' illustration based on banks " $A$ ", " $B$ " and " $C$ " rating manuals.

An interesting difference to mention is surely the category Relationship with the bank, which includes the period as well as the quality of the collaboration between the bank and the customer (thus the rated company). One of the rating systems take this indicator as the most important one with the weight of $40 \%$ (rounded), the second one uses this indicator with the $10 \%$ weight and the third one does not use this indicator at all (includes only problems in the relationship / previous collaboration with the customer as a warning signal, if existing). Even the later approach can make a good sense, considering the result of the rating process as a 
universal transferable number (which can, but does not need to be relevant in this situation). If the indicator "Relationship with the bank" is not applicable (new client with no history in the bank), the weight is given at 0 and the weights of the remaining criteria are equally increased - e.g. in the bank $A$ rating system all the remaining four qualitative indicators get the weight of $25 \%$ for a new client.

Another noteworthy difference between the rating systems are the unique indicators of rating system " $B$ ", concerning the divergence from company's planning in last three years and the company's business expectations including the bank's own view and opinion to these expectations.

\subsection{Scales of Rating Results}

Concerning the scales used for the final rating result, the differences between the rating systems are rather unessential. This is hardly a surprise, if we take into consideration that all the rating systems have one common goal: to estimate the PD (probability of default) of particular customers of the bank between 0 and $100 \%$ for the following year. The rating systems also have to fulfill some given requirements in order to be accepted as a tool for counting the capital requirements of Basel II or Basel III respectively.

On the high end of the scale, the banks $A$ and $B$ use rating grades 1-1 and 1-2 or 1 (AAAA) respectively for customers, who even do not have corresponding Moody's rating and $P D$. The bank $B$ describes this category as clients with "no credit risk at all", which is rarely a real situation. The bank A uses the first two grades just for sovereigns and other banks, thus even the best rated company clients can only get the grade 1-3, which corresponds with best grade of Moody's rating and real PD. Similar situation exists at the other two banks: the best company clients can reach he rating grade $1(A A A)$ or $1 A$ respectively, but even such a result is more of theoretical case.

On the lower end of the scale, all the banks use special grades for default clients, corresponding with Moody's grade $C$. The bank A uses as much as eight particular grades (8-1 to 8-8) for separate reason for default (like insolvency proceeding, overdue payments, restructuring etc.). An experienced user of the rating system can thus easily see the reason for the default grade of the rating. The bank $B$ distinguishes three default grades $(16,17$ and 18$)$ by the estimated next progress of the client's situation. One grade represents the situation where the bank believes in possible recovery of the transaction after restructuring. In the next grade the possible recovery is described as unlikely. The last grade is a definitive default of the transaction and the client, with no hope for recovery. The bank $\mathrm{C}$ use a method similar to bank $A$, but there are five grades of the default rating only. Another common feature for all three banks and their rating systems is, that the default rating grade (or more precisely any default grade) can be achieved only by existing risk factors (warning signals) or signs of default, but never by bad financial results or financial indicators only. The worst possible rating grade by financial statements only without any warning signals is 7 or 15 or $4 \mathrm{E}$ respectively. 
The Table 4 shows the scales used by all three mentioned banks, compared with the Moody's rating scale.

Table 4 The scales of rating results

\begin{tabular}{|c|c|c|c|c|}
\hline Rating A & Rating B & Rating C & Moody's & $\begin{array}{c}\text { Indicative PD in } 1 \\
\text { year }\end{array}$ \\
\hline $1-1$ & \multirow{2}{*}{1 (AAAA) } & & & \\
\hline $1-2$ & & & & \\
\hline $1-3$ & \multirow{2}{*}{$1(\mathrm{AAA})$} & \multirow{3}{*}{$1 \mathrm{~A}$} & Aaa & \multirow{2}{*}{$0.01 \%$} \\
\hline $2-1$ & & & Aa1 & \\
\hline $2-2$ & $1(\mathrm{AA}+)$ & & Aa2 & $0.02 \%$ \\
\hline $2-3$ & $1(A A)$ & $1 \mathrm{~B}$ & Aa3 & $0.02-0.03 \%$ \\
\hline $3-1$ & $1(\mathrm{AA}-)$ & $1 \mathrm{C}$ & $\mathrm{A} 1$ & $0.03 \%-0.04 \%$ \\
\hline $3-2$ & $1(A+)$ & $1 \mathrm{D}$ & $\mathrm{A} 2$ & $0.05 \%-0.06 \%$ \\
\hline \multirow{2}{*}{$3-3$} & $1(A)$ & $1 \mathrm{E}$ & \multirow{2}{*}{ A3 } & $0.07 \%-0.08 \%$ \\
\hline & $1(\mathrm{~A}-)$ & $2 \mathrm{~A}$ & & $0.08 \%-0.09 \%$ \\
\hline 4-1 & 2 & $2 B$ & Baa1 & $0.1 \%$ \\
\hline \multirow{3}{*}{$4-2$} & 3 & $2 \mathrm{C}$ & \multirow{3}{*}{ Baa2 } & \multirow{3}{*}{$0.1-0.2 \%$} \\
\hline & & $2 \mathrm{D}$ & & \\
\hline & 4 & $2 \mathrm{E}$ & & \\
\hline 4-3 & 5 & $3 \mathrm{~A}$ & Baa3 & $0.2 \%-0.5 \%$ \\
\hline $5-1$ & 6 & $3 B$ & Ba1 & $0.6 \%-0.7 \%$ \\
\hline \multirow{2}{*}{$5-2$} & 7 & \multirow[b]{2}{*}{$3 C$} & \multirow{2}{*}{$\mathrm{Ba} 2$} & \multirow{2}{*}{$0.8 \%-1.6 \%$} \\
\hline & 8 & & & \\
\hline \multirow{2}{*}{$5-3$} & \multirow{2}{*}{9} & $3 \mathrm{D}$ & \multirow{2}{*}{ Ba3 } & \multirow{2}{*}{$1.6 \%-2.4 \%$} \\
\hline & & $3 \mathrm{E}$ & & \\
\hline \multirow{3}{*}{$6-1$} & 10 & \multirow{2}{*}{$4 \mathrm{~A}$} & \multirow{2}{*}{ B1 } & \multirow{2}{*}{$2.4 \%-5.4 \%$} \\
\hline & 11 & & & \\
\hline & 12 & \multirow{2}{*}{$4 B$} & \multirow{2}{*}{ B2 } & $5.4 \%-12.2 \%$ \\
\hline $6-2$ & 13 & & & \\
\hline \multirow[t]{2}{*}{$6-2$} & 14 & $4 \mathrm{C}$ & \multirow{2}{*}{ B3 } & \multirow{2}{*}{$12.2 \%-17 \%$} \\
\hline & & $4 \mathrm{D}$ & & \\
\hline 7 & \multirow{2}{*}{15} & \multirow{2}{*}{$4 \mathrm{E}$} & Caa 1-3 & \multirow{2}{*}{$17 \%-100 \%$} \\
\hline 7 & & & $\mathrm{Ca}$ & \\
\hline \multirow{5}{*}{$8-1-8-8$} & 16 & $5 \mathrm{~A}$ & & \\
\hline & & $5 B$ & & \\
\hline & 17 & $5 \mathrm{C}$ & $\mathrm{C}$ & Default \\
\hline & & $5 \mathrm{D}$ & & \\
\hline & 18 & $5 \mathrm{E}$ & & \\
\hline
\end{tabular}

Note: The PDs are rounded.

Default (defined according to Basel II) $=90$ days past due or unlikely to pay. Source: Author by using banks $A, B$ and $C$ rating manuals 


\section{Conclusions}

The result of the research shows, that the structures of compared bank's internal rating systems are quite similar, based on integration of hard-facts rating based on quantitative indicators and soft-facts rating based on qualitative indicators, with possible additional steps according to the client (e.g. existing or non non-existing guarantor, external rating etc.). My conclusions about hard-facts part of credit rating systems are in line e.g. with the recent research of Weissova, Kollar and Siekelova (2015), who deal with the situation in Slovakia.

Concerning the quantitative indicators (i), the highest emphasis is put on the capital structure of a company (whether in the form of Equity to Liabilities or Equity to Total assets) in all three compared rating systems. Cash Flow to Liabilities, Profit to Sales and Trade payables and Notes payable to Sales are other indicators used universally; the other indicators used for the calculation differ in the systems, as well as the total number of indicators (from 6 to 9). Most of the indicators mentioned here appear e.g. in the paper of Van Laere and Baesens (2010), concerning the rating systems in insurance branch. The relatively high similarity of the structures of compared bank's internal rating systems as well as the of the hard-facts indicators corresponds to the results of Danielsson (2002) and Danielsson, Song Shin and Zigrand (2004), who, however, focused on models of market risk and on value-at-risk models (VaR).

The size of the rated company is included under hard-facts calculation just in one of the three cases mentioned, where the more turnover the rated company makes, the more weight the hard-facts have in counting the final rating. Thus the size of the company is not a real hard - facts indicator and the mentioned rating systems in German-speaking environment currently do not reflect the Bakhtiari's (2017) conclusions about credit rating of firms in the USA, where the rating systems favour medium-sized productive firms and very large but not so productive companies. The relationship between the size of the company, the rating results and the real PD (especially in European area) can be seen as an interesting topic for following research.

For soft-facts (ii) all rating systems agree on some of the basic categories (e.g. the quality of the management, market situation and sensitivity of the rated entity to market fluctuations etc.), but otherwise the number and the topics of the queries overlap only partially.

My conclusions can be useful for any bank or financial institution, considering the development of their own credit rating system, investing in the purchase of an existing corporate rating solution or, where appropriate, improving or updating the rating system already in use. As other surveys like Jankowitsch, Pichler and Schwaiger (2007) show, investment in the rating system can bring not only a reduction in Basel's required capital held in the bank but also a reduction in credit losses. 


\section{References}

Bakhtiari, S. (2017). Corporate Credit Ratings: Selection on Size or Productivity? International Review of Economics \& Finance, 49, pp. 84-101. DOI: 10.1016/j.iref.2017.01.023.

Bank "A", "B" and "C" Rating Manuals (2011), (2004), (2008).

Berg, T. and Koziol, P. (2017). An Analysis of the Consistency of Banks' Internal Ratings. Journal of Banking \& Finance, 78, pp. 27-41. DOI: 10.1016/j.jbankfin.2017.01.013.

Basel II (2006). Basel II: International Convergence of Capital Measurement and Capital Standards: A Revised Framework - Comprehensive Version. Available at: http://www.bis.org/publ/bcbs128.htm.

BIS (2010). Basel III: Ein globaler Regulierungsrahmen für widerstandsfähigere Banken und Bankensysteme. Available at: http://www.bundesbank.de/ Redaktion/DE/Downloads/Aufgaben/Bankenaufsicht/Basel/2010_12_basel3_ein_g lobaler_regulierungsrahmen_fuer_widerstandsfaehigere_banken_und_bankensyst eme.pdf?_blob=publicationFile.

Danielsson, J. (2002). The Emperor Has No Clothes: Limits to Risk Modelling. Journal of Banking \& Finance, 26, pp. 1273-1296. DOI: 10.1016/S03784266(02)00263-7.

Daníelsson, J., Son Shin, H. and Zigrand, J.-P. (2004). The Impact of Risk Regulation on Price Dynamics. Journal of Banking \& Finance, 28, pp. 1069-1087. DOI: $10.1016 /$ S0378-4266(03)00113-4.

Fracassi, C., Petry, S. and Tate, G. (2016). Does Rating Analyst Subjectivity Affect Corporate Debt Pricing? Journal of Financial Economics, 120, pp. 514-538. DOI: 10.1016/j.jfineco.2016.02.006.

Jankowitsch, R., Pichler, S. and Schwaiger, W.S.A. (2007). Modelling the Economic Value of Credit Rating Systems. Journal of Banking \& Finance, 31(1), pp. 181-198. DOI: $10.1016 /$ j.jbankfin.2006.01.003.

Jeon, D.-S. and Lovo, S. (2013). Credit Rating Industry: A Helicopter Tour of Stylized Facts and Recent Theories. International Journal of Industrial Organization, 31, pp. 643-651. DOI: 10.1016/j.ijindorg.2013.02.004.

Spuchláková, E., Valašková, K. and Adamko, P. (2015). The Credit Risk and its Measurement, Hedging and Monitoring. Procedia Economics and Finance, 24, pp. 675-681. DOI: 10.1016/S2212-5671(15)00671-1.

Van Laere, E., Baesens, B. (2010). The Development of a Simple and Intuitive Rating System Under Solvency II. Insurance: Mathematics and Economics, 46(3), pp. 500-510. DOI: 10.1016/j.insmatheco.2010.01.008.

Weissova, I., Kollar, B., Siekelova, A. (2015). Rating as a Useful Tool for Credit Risk Measurement. Procedia Economics and Finance, 26, pp. 278-285. DOI: 10.1016/S2212-5671(15)00853-9. 